\title{
Pemberian Biochar Jengkok Tembakau untuk Meningkatkan Hasil Ubijalar pada Lahan Kering Sub-Optimal
}

\author{
Increasing Sweet Potato Yield on Biochar Amendment Application on Sub-Optimal Dry \\ Land
}

\author{
Edyson Indawan ${ }^{1 *}$, Sri Umi Lestari ${ }^{1}$, Nurita Thiasari ${ }^{1}$ \\ ${ }^{1}$ Fakultas Pertanian, Universitas Tribhuwana Tunggadewi, Kota Malang, \\ Jawa Timur 65144 \\ ${ }^{*}$ Penulis untuk korespondensi: mankedlht@yahoo.com
}

\begin{abstract}
Biochar is a soil amendment that can improve soil fertility, increase crop yield and can reduce contamination. This study aimed to evaluate the sweet potato response to biochar application from tobacco industry waste. The combination of cultivar and dose of biochar implemented using a Split Plot Experiment Design with three replications. The cultivars placed 0n main plots and biochar doses on sub-plots. The thirteen cultivars covering 7 varieties (Kuningan Putih, Beta 1, Beta 2, Kuningan Merah, Sari, Boko, and Jago) plus six accession from Unitri and Brawijaya University collections (BIS OP-61-OP22 , 73-6 / 2, 73 OP-8, BIS OP-61, 73 OP-5, and BIS OP-61-9 -29). The biochar dose used was $\mathrm{B}_{0}(0 \mathrm{t} / \mathrm{ha})$ and $\mathrm{B}_{1}(5 \mathrm{t} / \mathrm{ha})$. The experimental unit is measuring $5 \mathrm{~m} \times 0.6 \mathrm{~m}$, consisting of single row and planted with a spacing of $25 \mathrm{~cm}$ in row or 20 cuttings/row). The storage root numbers, storage root weight, \% dry matter, Harvest Index (HI) and yields estimation are ditermined. The results showed that sweet potato cultivars gave a significant response to biochar application on fresh storage root weight, dry storage root weight, biomass dry weight, HI and storage root yields, but no interaction between cultivars and biochar doses. Storage root yield range of $8-21 \mathrm{t} /$ ha without biochar and $10-23 \mathrm{t} / \mathrm{ha}$ with biochar $5 \mathrm{t} / \mathrm{ha}$, except for Beta 1 and Boko. The use of biochar of $5 \mathrm{t} / \mathrm{ha}$ can increase storage root yields ranging from $8-45 \%$.
\end{abstract}

Keywords: biochar from tobacco industry waste, Sweet potato, storage root fresh weight

\begin{abstract}
ABSTRAK
Biochar merupakan bahan pembenah tanah yang mampu memperbaiki kesuburan tanah, meningkatan hasil tanaman dan dapat mengurangi kontaminasi. Penelitian ini mempunyai tujuan untuk mengevaluasi respon ubijalar terhadap pemberian biochar jengkok tembakau. Kombinasi perlakuan kultivar ubijalar dan pemberian dosis biochar dipilih dan dilaksanakan menggunakan rancangan percobaan Split Plot yang diulang tiga kali. Kultivar ubijalar diletakkan sebagai main plot dan dosis biochar sebagai sub-plot. Bahan tanaman ubijalar terdiri dari 13 kultivar, meliputi 7 varietas (Kuningan Putih, Beta 1, Beta 2, Kuningan merah, Sari, Boko, dan Jago) ditambah 6 klon unggulan koleksi Unitri dan UB (BIS OP-61-OP-22, 73-6/2, 73 OP-8, BIS OP-61, 73 OP-5, dan BIS OP-61-9 -29). Dosis biochar yang digunakan adalah $\mathrm{B}_{0}(0 \mathrm{t} / \mathrm{ha})$ dan $\mathrm{B}_{1}(5 \mathrm{t} / \mathrm{ha})$. Unit percobaan berukuran panjang $5 \mathrm{~m}$ x $0.6 \mathrm{~m}$, terdiri dari satu gulud dan ditanami dengan jarak tanam $25 \mathrm{~cm}$ dalam baris (20 stek/gulud). Parameter yang diamati meliputi: jumlah umbi, bobot umbi, bobot brangkasan, \% BK umbi, \% BK brangkasan, BK umbi dan BK Brangkasan, estimasi hasil
\end{abstract}


umbi (t/ha) dan hasil brangkasan serta Indeks Panen (IP). Hasil penelitian menunjukkan bahwa kultivar ubijalar memberikan respon yang sangat nyata/nyata terhadap pemberian biochar pada parameter bobot umbi segar, BK umbi, BK biomass, IP dan estimasi hasil umbi, namun tidak ada interaksi antara kultivar dengan dosis biochar. Kisaran hasil umbi mencapai sebesar $8-21 \mathrm{t} / \mathrm{ha}$ tanpa pemberian biochar dan $10-23 \mathrm{t} / \mathrm{ha}$ dengan penggunaan biochar 5 t/ha, kecuali kultivar Beta 1 dan Boko. Penggunaan biochar sebesar 5 t/ha mampu meningkatkan hasil umbi berkisar antara $8-45 \%$.

Kata kunci: biochar jengkok tembakau, kultivar ubijalar, hasil umbi segar

\section{PENDAHULUAN}

Lahan-lahan pertanian di Pulau Jawa pada umumnya banyak yang telah terdegradasi dan mengalami penurunan kesuburan tanah. Menurut Sitorus et al. (2011) kriteria lahan telah terdegradasi antara lain didasarkan pada variabel bahan induk, tekstur fraksi debu, jenis penggunaan lahan, tindakan konservasi, lereng, dan variabel sifat kimia $(\mathrm{pH}, \mathrm{C}$-organik, N-total, P-tersedia, Ca, Mg, K, Na, KTK, KB, Al-dd dan $\mathrm{H}$-dd. Fraksi debu dengan persentase antara $20-40 \%$ dan P-tersedia dengan kadar yang sangat rendah $(<3 \mathrm{ppm})$ dengan peruntukan budidaya pertanian tanaman pangan yang intesif termasuk pada kriteria terdegradasi berat. Lahan yang telah terdegradasi secara berat menjadi salah satu penyebab utama rendahnya produktivitas tanaman.

Tanaman ubijalar [Ipomoea batatas (L.) Lam.] merupakan tanaman pangan penghasil pati yang sangat efisien, lebih efisien dibandingkan dengan padi, jagung maupun kentang (Kozai et al., 1999), sesuai untuk usahatani subsisten di berbagai wilayah di Indonesia (Zuraida, 2003). Tanaman ini masih dapat tumbuh dengan baik pada lahan-lahan marginal dengan curah hujan yang tidak menentu (Motza et al., 2015). Namun demikian, pemupukan yang optimal diperlukan ubijalar untuk mencapai potensi produksinya. Potensi produksi dalam satu kali musim tanam (4 bulan) ubijalar mampu menghasilkan 30 40 ton umbi segar tiap hektarnya (Saleh dan Hartojo, 2003) dengan takaran dosis pupuk sebesar 100-200 kg Urea + 100 kg SP36 + $100 \mathrm{~kg} \mathrm{KCl}$ per hektar dan sangat baik bila ditambahkan pupuk kandang yang diberikan bersamaan pembuatan guludan (Balitkabi, 2010). Hasil ubijalar di lahan percobaan di North Carolina University lebih tinggi dari 65 t/ha (Ziska et al., 2009). Hasil ubijalar rata-rata di tingkat petani hanya mencapai 10 t/ha (Balitkabi, 2010). Rendahnya hasil ubijalar di tingkat petani disebabkan oleh banyak faktor, diduga antara lain penggunaan varietas lokal dengan daya hasil rendah dan kondisi lahan-lahan pertanian di Indonesia telah mengalami degradasi pada tingkat sedang sampai dengan berat (Sitorus et al., 2011).

Lahan yang mendapatkan pupuk anorganik secara terus-menerus memperlihatkan penurunan produktivitas dan cenderung mengalami defisiensi hara sekunder maupun mikro nutrien (Sheth et al., 2017). Penambahan bahan pembenah tanah sudah diperlukan untuk mengembalikan kesuburan tanahnya. Biochar merupakan salah satu bahan pembenah tanah yang mampu memperbaiki kesuburan tanah (Ding et al., 2016). Biochar dapat dibuat dengan memanfaatkan limbah hasil pertanian maupun industri. Jengkok tembakau adalah sisa-sisa produksi industri rokok yang sebagian besar berasal dari daun tembakau dan bunga cengkeh yang telah dibuang ke tempat pembuangan limbah. Produksi limbah jengkok tembakau cukup tinggi, lebih dari 20 t tiap hari, berpotensi sebagai sumber pencemaran lingkungan (Talkah, 2010). Saat ini jengkok tembakau ini telah diproduksi menjadi biochar, oleh karena itu melalui penelitian ini perlu dievaluasi bagaimana respon keragaan kultivar-kultivar ubijalar terhadap pemberian biochar jengkok tembakau yang diaplikasikan pada lahan pertanian yang telah secara intensif digunakan untuk 
budidaya tanaman. Penelitian ini bertujuan untuk mengevaluasi respon ubijalar terhadap pemberian biochar jengkok tembakau.

\section{BAHAN DAN METODE}

\section{Tempat dan waktu Penelitian}

Penelitian ini dilaksanakan di

Kebun Percobaan Universitas Brawijaya yang berlokasi di Desa Jatikerto, Kecamatan Kromengan, Kab. Malang, sejak Maret - Juli 2017. Lokasi penelitian mempunyai jenis tanah Alfisol dan berada pada ketinggian $352 \mathrm{~m}$ diatas permukaan laut, termasuk kriteria lahan kering dengan $\mathrm{pH}$ tanah masam $\left(\mathrm{pH} \mathrm{H}_{2} \mathrm{O}\right.$ 5.5), kadar Corganik dan $\mathrm{N}$-total yang sangat rendah $(\mathrm{C}$ org 0.87\%; N-total 0.09\%), kadar $\mathrm{P}$ juga sangat rendah $(0.76 \mathrm{P} \mathrm{mg} / \mathrm{kg})$. Tekstur tanahnya (17\% pasir, $35 \%$ debu dan $48 \%$ liat) mempunyai fraksi debu yang berada pada kisaran antara $20-40 \%$. Secara detail hasil analisis tanah total (Tabel 1).

\section{Bahan dan Alat Penelitian}

Bahan tanaman yang digunakan pada penelitian ini terdiri dari 13 kultivar ubijalar, meliputi 7 varietas (Kuningan Putih, Beta 1, Beta 2, Kuningan merah, Sari, Boko, dan Jago) ditambah 6 klon-klon unggulan koleksi Unitri dan UB (BIS OP61-OP-22, 73-6/2, 73 OP-8, BIS OP-61, 73 OP-5, dan BIS OP-61-9-29). Secara lengkap disajikan pada Tabel 2. Biochar jengkok tembakau yang digunakan pada penelitian ini diperoleh dari PT Gudang Garam Kediri. Pupuk dasar untuk paket teknologi ubijalar yang digunakan adalah PONSKA (15-15-15) dengan dosis 400 $\mathrm{kg} / \mathrm{ha}$ untuk menggantikan dosis standar ubijalar dengan takaran dosis pupuk sebesar 100-200 kg Urea + $100 \mathrm{~kg} \mathrm{SP36} \mathrm{+} 100 \mathrm{~kg}$ $\mathrm{KCl}$ per hektar.

Tabel 1. Hasil analisis sampel tanah di lokasi percobaan

\begin{tabular}{llrl}
\hline No & Sifat Tanah & Hasil pengukuran & Kriteria (Balittanah, 2005) \\
\hline 1. & $\mathrm{pH}\left(\mathrm{H}_{2} \mathrm{O}\right)$ & 5.5 & Masam \\
2. & C-organik $(\%)$ & 0.87 & Sangat rendah \\
3. & N-total $(\%)$ & 0.09 & Sangat rendah \\
4. & $\mathrm{C} / \mathrm{N}$ & 10 & Rendah \\
5. & $\mathrm{P}-\mathrm{Bray} 1(\mathrm{mg} / \mathrm{kg})$ & 0.76 & Sangat rendah \\
6. & $\mathrm{K}(\mathrm{me} / 100 \mathrm{~g})$ & 2.61 & Sangat tinggi \\
7. & $\mathrm{Na}(\mathrm{me} / 100 \mathrm{~g})$ & 1.27 & Sangat tinggi \\
8. & $\mathrm{Ca}(\mathrm{me} / 100 \mathrm{~g})$ & 6.57 & Sedang \\
9. & $\mathrm{Mg}(\mathrm{me} / 100 \mathrm{~g})$ & 2.19 & Tinggi \\
10. & $\mathrm{KTK}(\mathrm{me} / 100 \mathrm{~g})$ & 18.96 & Sedang \\
11. & $\mathrm{KB}(\%)$ & 67 & Tinggi \\
12. & Pasir $(\%)$ & 17 & \\
13. & Debu $(\%)$ & 35 & Liat \\
14. & Liat $(\%)$ & 48 & \\
\hline
\end{tabular}

\section{Metode Penelitian}

Rancangan percobaan Split Plot digunakan dengan tiga ulangan. Kultivar ubijalar diletakkan sebagai main plot dan dosis biochar dengan dosis 0 dan 5 t/ha diletakkan sebagai sub-plot. Ukuran petak percobaan panjang $5 \mathrm{~m}$ dan lebar $0.6 \mathrm{~m}$, sebagai plot baris tunggal, ditanami stek ubijalar dengan jarak dalam baris $25 \mathrm{~cm}$, sehingga terdapat 20 stek per plot percobaan. Pemberian biochar sesuai perlakukan diberikan satu minggu sebelum tanam. Semua plot percobaan diberi pupuk dasar PONSKA (15-15-15) dengan dosis $400 \mathrm{~kg} / \mathrm{ha}$ dan diberikan dua kali, pertama sebanyak $1 / 3$ bagian diberikan pada umur tanaman satu minggu setelah tanam dan sisanya diberikan pada umur tanaman 1.5 bulan setelah tanam dengan cara ditugal. Penyiangan dan pembalikan batang dilakukan bersamaan dengan tindakan turun gulud dan naik gulud sesuai teknologi 
budidaya baku untuk ubijalar. Tanaman dipelihara dan dipanen pada umur 4 bulan setelah tanam. Parameter yang diamati meliputi jumlah umbi, bobot umbi, bobot brangkasan, \% bobot kering (BK) umbi, \%
BK brangkasan, BK umbi, BK biomass dan indeks panen (IP) serta ratio shoot/root. Namun yang disajikan pada makalah ini hanya sebagaian dari parameter yang diamati.

Tabel 2. Kultivar ubijalar yang digunakan pada penelitian

\begin{tabular}{|c|c|c|c|}
\hline No & Klon & Karakter & Pedigree \\
\hline 1. & Kuningan Putih & Bobot kering tinggi & $\begin{array}{l}\text { Varietas lokal dari Kabupaten Kuningan (Jawa } \\
\text { barat) }\end{array}$ \\
\hline 2. & $\begin{array}{l}\text { BIS OP-61-OP- } \\
22\end{array}$ & $\begin{array}{l}\text { Kadar } \mathrm{Fe} \text { dan } \mathrm{Zn} \\
\text { tinggi }\end{array}$ & Hasil persilangan terbuka klon BIS OP-61 no 22 \\
\hline 3. & $73-6 / 2$ & Bobot kering tinggi & $\begin{array}{l}\text { Klon unggulan hasil seleksi Prof. Dr.Ir. Nur } \\
\text { Basuki (alm.) koleksi UB }\end{array}$ \\
\hline 4. & Beta 1 & Beta karoten tinggi & Varietas yang telah dilepas Tahun 2009 \\
\hline 5. & Beta 2 & Beta karoten tinggi & Varietas yang telah dilepas Tahun 2009 \\
\hline 6. & Kuningan Merah & Beta karoten tinggi & $\begin{array}{l}\text { Varietas lokal dari Kabupaten Kuningan (Jawa } \\
\text { barat) }\end{array}$ \\
\hline 7. & 73 OP-8 & Protein tinggi & Hasil persilangan terbuka dari klon induk $73-6 / 2$ \\
\hline 8. & BIS OP-61 & Protein tinggi & $\begin{array}{l}\text { Hasil persilangan terbuka klon BIS-214 yang } \\
\text { berasal dari introduksi (Nigeria) }\end{array}$ \\
\hline 9. & $73 \mathrm{OP}-5$ & Protein tinggi & Hasil persilangan terbuka dari klon induk $73-6 / 2$ \\
\hline 10. & Sari & Kontrol & Varietas yang telah dilepas Tahun 2001 \\
\hline 11. & Boko & Kontrol & Varietas yang telah dilepas Tahun 2001 \\
\hline 12. & Jago & Kontrol & Varietas yang telah dilepas Tahun 2001 \\
\hline 13. & BIS OP-61-q-29 & Brangkasan tinggi & $\begin{array}{l}\text { Hasil persilangan terkontrol dari BIS OP-61 } \\
\text { yang dijadikan induk betina no } 29\end{array}$ \\
\hline
\end{tabular}

Analisis Data

Data dianalisis dengan analisis ragam dan nilai reratanya disajikan secara deskriptif, tidak dilanjutkan dengan uji beda antar rata-rata. Dasar pertimbangan yang dapat diambil tidak diletakkan pada perbedaan antar kultivar. Adanya perbedaan pada aplikasi penggunaan biochar sudah jelas terlihat apabila ditemukan terdapat perbedaan nyata maka pemberian biochar $5 \mathrm{t} / \mathrm{ha}$ pasti berbeda terhadap kontrol atau tanpa pemberian biochar.

\section{HASIL}

Keragaan ketiga belas kultivar yang dievaluasi (Tabel 3, 4, dan 5) terhadap pemberian biochar jengkok tembakau sebesar 5 t/ha berdasarkan parameter yang diamati menunjukkan perbedaan yang nyata/sangat nyata, terutama bobot umbi/tanaman, bobot kering umbi, bobot kering biomass, IP dan estimasi hasil umbi/ha. Biochar jengkok tembakau tidak mampu memberikan pengaruh terhadap jumlah umbi maupun bobot brangkasan (Tabel 6 dan 7).

Bobot umbi dari masing-masing kultivar hanya berkisar antara $0.20-0.53$ $\mathrm{kg}$ umbi segar per tanaman tanpa pemberian biochar, namun meningkat menjadi berkisar antara $0.25-0.57 \mathrm{~kg} /$ tanaman ketika diberi perlakuan biochar sebanyak 5 t/ha. Hasil rata-rata per tanaman dapat digunakan untuk estimasi hasil umbi segar dengan nilai konversi jumlah populasi tanaman ubijalar dengan jarak tanam dalam baris 25 $\mathrm{cm}$ sebesar 40000 tanaman/ha, maka diperoleh nilai kisaran hasil ubi sebesar 8 $21 \mathrm{t}$ umbi segar/ha pada perlakuan tanpa biochar, sedangkan dengan pemberian 
biochar dapat dihasilkan hasil umbi segar berkisar antara $10-22.70 \mathrm{t} /$ ha (Tabel 5). Dari angka perestase kenaikan hasil umbi akibat pemberian biochar mencapai 8 -
$45 \%$ dibanding hasil umbi tanpa pemberian biochar (Tabel 5), kecuali untuk varietas Bea 1 dan Boko yang justru menurun ketika diberi biochar.

Tabel 3. Rerata jumlah umbi, bobot umbi, bobot brangkasan, dan $\%$ bobot kering umbi dari 13 kultivar ubijalar dengan perlakuan pemberian Biochar $\left(\mathrm{B}_{1}=5 \mathrm{t} / \mathrm{ha}\right)$ dan tanpa biochar

\begin{tabular}{|c|c|c|c|c|c|c|c|c|c|}
\hline \multirow[t]{2}{*}{ No } & \multirow[t]{2}{*}{ Klon } & \multicolumn{2}{|c|}{$\begin{array}{l}\text { Jumlah } \\
\text { umbi/tan }\end{array}$} & \multicolumn{2}{|c|}{$\begin{array}{l}\text { Bobot umbi } \\
(\mathrm{kg} / \tan )\end{array}$} & \multicolumn{2}{|c|}{$\begin{array}{c}\text { Bobot } \\
\text { brangkasan } \\
(\mathrm{kg} / \mathrm{tan})\end{array}$} & \multicolumn{2}{|c|}{$\%$ BK umbi } \\
\hline & & $\mathrm{B}_{0}$ & $\mathrm{~B}_{1}$ & $\mathrm{~B}_{0}$ & $\mathrm{~B}_{1}$ & $\mathrm{~B}_{0}$ & $\mathrm{~B}_{1}$ & $\mathrm{~B}_{0}$ & $\mathrm{~B}_{1}$ \\
\hline 1 & Kuningan Putih & 1.72 & 1.61 & 0.30 & 0.44 & 0.44 & 0.50 & 31.43 & 32.48 \\
\hline 2 & BIS OP-61-OP-22 & 2.22 & 2.52 & 0.53 & 0.57 & 0.31 & 0.27 & 27.94 & 29.58 \\
\hline 3 & $73-6 / 2$ & 2.30 & 2.40 & 0.34 & 0.48 & 0.30 & 0.32 & 33.36 & 32.66 \\
\hline 4 & Beta 1 & 2.00 & 5.23 & 0.33 & 0.31 & 0.53 & 0.59 & 21.77 & 22.45 \\
\hline 5 & Beta 2 & 2.30 & 3.07 & 0.37 & 0.52 & 0.30 & 0.33 & 23.96 & 22.72 \\
\hline 6 & Kuningan Merah & 2.04 & 1.55 & 0.31 & 0.38 & 0.57 & 0.43 & 23.40 & 24.95 \\
\hline 7 & 73-OP-8 & 1.72 & 2.03 & 0.20 & 0.25 & 0.39 & 0.42 & 24.06 & 24.23 \\
\hline 8 & BIS OP-61 & 1.49 & 2.00 & 0.26 & 0.31 & 0.54 & 0.58 & 33.34 & 34.95 \\
\hline 9 & 73 OP-5 & 2.08 & 2.16 & 0.47 & 0.54 & 0.42 & 0.42 & 28.02 & 27.51 \\
\hline 10 & Sari & 1.82 & 2.54 & 0.34 & 0.44 & 0.14 & 0.22 & 27.36 & 28.29 \\
\hline 11 & Boko & 1.89 & 2.12 & 0.28 & 0.29 & 0.54 & 0.52 & 31.10 & 31.58 \\
\hline 12 & Jago & 1.50 & 1.28 & 0.29 & 0.33 & 0.26 & 0.27 & 32.30 & 32.18 \\
\hline 13 & BIS OP-61-ㅇ-29 & 2.68 & 3.02 & 0.44 & 0.47 & 0.43 & 0.43 & 28.76 & 28.07 \\
\hline \multirow{2}{*}{\multicolumn{2}{|c|}{$\begin{array}{l}\text { Tingkat signifikansi antar } \\
\text { kultivar }\end{array}$}} & \multirow{2}{*}{\multicolumn{2}{|c|}{ ns }} & \multicolumn{2}{|c|}{$* *$} & \multicolumn{2}{|c|}{$* *$} & \multicolumn{2}{|c|}{ ** } \\
\hline & & & & \multicolumn{2}{|c|}{0.13} & \multicolumn{2}{|c|}{0.29} & \multicolumn{2}{|c|}{3.63} \\
\hline
\end{tabular}

Tabel 4. Rerata \% bobot kering brangkasan, bobot kering umbi, bobot kering brangkasan dan bobot kering biomass dari 13 kultivar ubijalar dengan perlakuan pemberian Biochar $\left(\mathrm{B}_{1}=5 \mathrm{t} / \mathrm{ha}\right)$ dan tanpa biochar

\begin{tabular}{lcccccccr}
\hline \multirow{2}{*}{ Klon } & $\%$ BK Brangkasan & \multicolumn{2}{c}{$\begin{array}{c}\text { BK Umbi } \\
(\mathrm{kg} / \mathrm{tan})\end{array}$} & \multicolumn{2}{c}{$\begin{array}{c}\text { BK Brangkasan } \\
(\mathrm{Kg} / \mathrm{tan})\end{array}$} & \multicolumn{2}{c}{$\begin{array}{c}\text { BK Biomass } \\
(\mathrm{kg} / \mathrm{tan})\end{array}$} \\
\cline { 2 - 10 } & $\mathrm{B}_{0}$ & $\mathrm{~B}_{1}$ & $\mathrm{~B}_{0}$ & $\mathrm{~B}_{1}$ & $\mathrm{~B}_{0}$ & $\mathrm{~B}_{1}$ & $\mathrm{~B}_{0}$ & $\mathrm{~B}_{1}$ \\
\hline Kuningan Putih & 17.11 & 15.17 & 0.10 & 0.14 & 0.08 & 0.08 & 0.17 & 0.22 \\
BIS OP-61-OP-22 & 14.93 & 14.83 & 0.15 & 0.17 & 0.05 & 0.04 & 0.19 & 0.21 \\
73-6/2 & 17.35 & 16.61 & 0.11 & 0.16 & 0.05 & 0.05 & 0.16 & 0.21 \\
Beta 1 & 18.63 & 16.78 & 0.07 & 0.07 & 0.10 & 0.10 & 0.17 & 0.17 \\
Beta 2 & 17.20 & 16.63 & 0.09 & 0.12 & 0.05 & 0.06 & 0.14 & 0.17 \\
Kuningan Merah & 17.82 & 15.69 & 0.07 & 0.09 & 0.10 & 0.07 & 0.17 & 0.16 \\
73-OP-8 & 17.05 & 18.91 & 0.05 & 0.06 & 0.07 & 0.08 & 0.11 & 0.14 \\
BIS OP-61 & 16.18 & 16.72 & 0.09 & 0.11 & 0.09 & 0.10 & 0.17 & 0.21 \\
73 OP-5 & 15.90 & 15.39 & 0.13 & 0.15 & 0.07 & 0.07 & 0.20 & 0.21 \\
Sari & 19.35 & 20.59 & 0.09 & 0.12 & 0.03 & 0.05 & 0.12 & 0.17 \\
Boko & 17.20 & 16.65 & 0.09 & 0.09 & 0.09 & 0.09 & 0.18 & 0.18 \\
Jago & 18.24 & 19.28 & 0.09 & 0.11 & 0.05 & 0.05 & 0.14 & 0.16 \\
BIS OP-61-9-29 & 17.58 & 16.49 & 0.13 & 0.13 & 0.07 & 0.07 & 0.20 & 0.20 \\
\hline Tingkat signifikansi & & $* *$ & & $* *$ & & $* *$ & & $* *$ \\
antar kultivar & & 3.56 & & 0.05 & & 0.06 & & 0.05 \\
\hline
\end{tabular}


Bobot brangkasan tanaman diikutkan sebagai parameter pengamatan untuk antisipasi pemanfaatannya sebagai bahan substitusi hijauan pakan ternak. Dari ketiga belas kultivar yang dievaluasi diperoleh bobot segar brangkasan berkisar antara $0.30-0.57 \mathrm{~kg} /$ ha (Tabel 3) atau setara dengan $5.57-22.92$ t/ha pada perlakuan tanpa pemberia biochar dan berkisar antara $8.75-23.67$ t/ha dengan pemberian biochar. Pemberian biochar tidak berpengaruh dalam meningkatkan bobot brangkasan. Banyak kultivar yang justru terjadi penurunan hasil brangkasannya ketika diberi perlakuan biochar (Tabel 5), misalnya kultivar BIS OP-61-OP-22, Kuningan Merah, 73 OP-5, dan Boko.

Tabel 5. Rerata indeks panen (IP), estimasi hasil umbi dan brangkasan segar serta persentase kenaikan hasil umbi maupun brangkasan segar pada 13 kultivar ubijalar dengan perlakuan pemberian Biochar $\left(B_{1}=5 \mathrm{t} / \mathrm{ha}\right)$ dan tanpa biochar

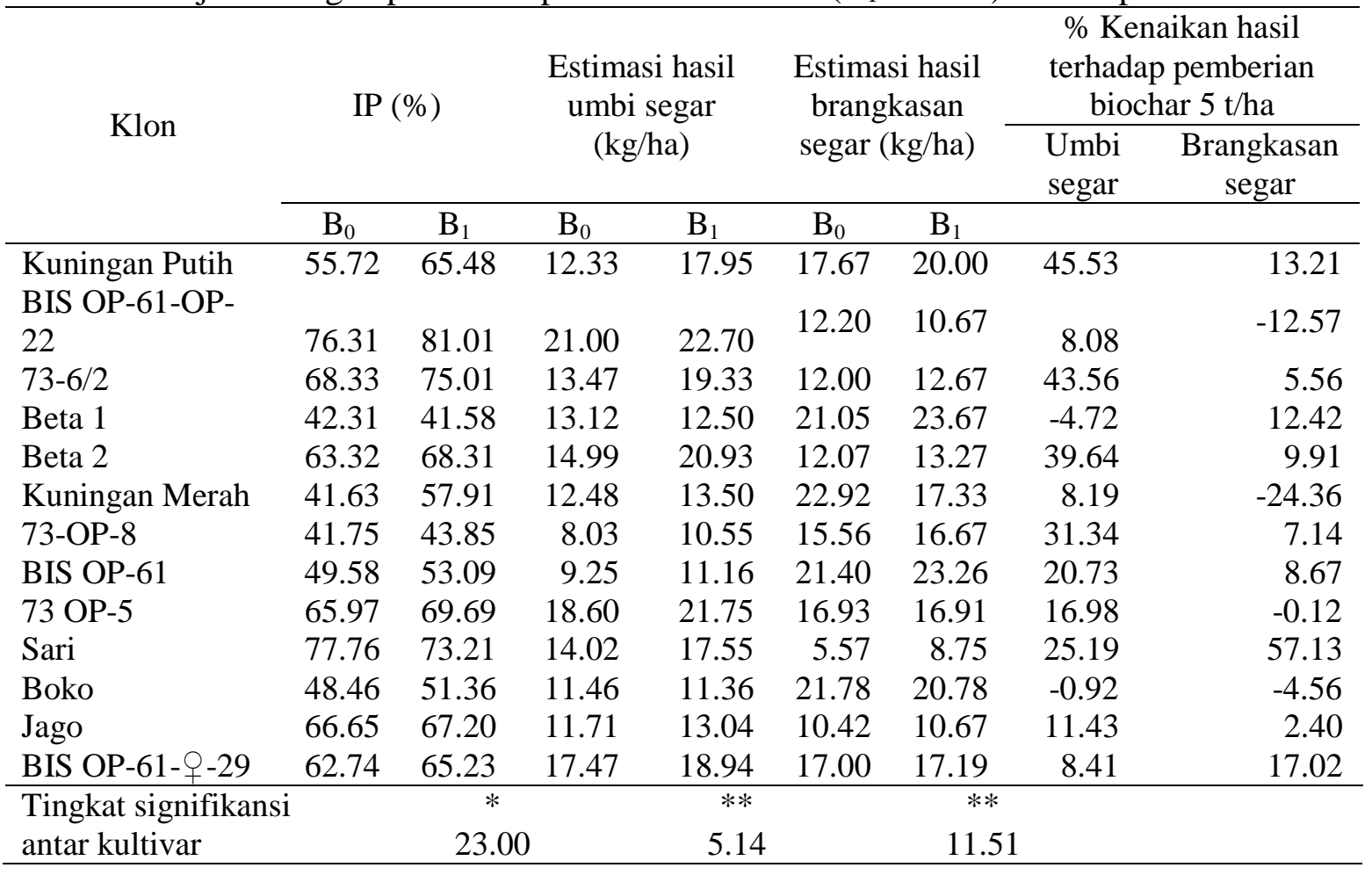

Tabel 6. Analisis ragam jumlah umbi, bobot umbi, bobot brangkasan, $\% \mathrm{BK}$ umbi, dan $\%$ BK brangkasan beberapa kultivar ubijalar yang diberi perlakuan biochar jengkok tembakau

\begin{tabular}{|c|c|c|c|c|c|c|c|c|c|c|c|}
\hline \multirow[b]{2}{*}{ Sumber Keragaman } & \multirow[b]{2}{*}{$\mathrm{db}$} & \multicolumn{10}{|c|}{ Kuadrat tengah } \\
\hline & & \multicolumn{2}{|c|}{$\begin{array}{l}\text { Jumlah } \\
\text { Umbi/Tan }\end{array}$} & \multicolumn{2}{|c|}{$\begin{array}{c}\text { Bobot } \\
\text { Umbi } \\
\text { (Kg/Tan) }\end{array}$} & \multicolumn{2}{|c|}{$\begin{array}{c}\text { Bobot } \\
\text { Brangkasan } \\
(\mathrm{Kg} / \mathrm{Tan})\end{array}$} & \multicolumn{2}{|c|}{$\%$ BK Umbi } & \multicolumn{2}{|c|}{$\begin{array}{c}\% \text { BK } \\
\text { Brangkasan }\end{array}$} \\
\hline Rep & 2 & 0.01 & ns & 0.06 & $* *$ & 0.211 & $* *$ & 2.36 & $\mathrm{~ns}$ & 78.16 & $* *$ \\
\hline Kultivar (main plot) & 12 & 3.48 & ns & 0.06 & $* *$ & 0.150 & $* *$ & 96.20 & $* *$ & 10.36 & ns \\
\hline Error (a) & 24 & 2.04 & & 0.01 & & 0.032 & & 5.05 & & 4.86 & \\
\hline Biochar & 1 & 5.94 & ns & 0.08 & $* *$ & 0.010 & ns & 2.69 & ns & 2.64 & ns \\
\hline Kultivar x Biochar & 12 & 2.01 & ns & 0.00 & $\mathrm{~ns}$ & 0.004 & ns & 1.41 & ns & 2.37 & ns \\
\hline Error (b) & 26 & 1.98 & & 0.01 & & 0.007 & & 1.42 & & 2.13 & \\
\hline
\end{tabular}


Tabel 7. Analisis ragam BK umbi, BK brangkasan, BK Biomass dan IP beberapa kultivar ubijalar yang diberi perlakuan biochar jengkok tembakau

\begin{tabular}{|c|c|c|c|c|c|c|c|c|c|c|c|c|c|}
\hline \multirow{3}{*}{$\begin{array}{c}\text { Sumber } \\
\text { keragaman }\end{array}$} & & \multicolumn{12}{|c|}{ Kuadrat tengah } \\
\hline & \multirow[t]{2}{*}{$\begin{array}{l}d \\
b\end{array}$} & \multicolumn{2}{|c|}{$\begin{array}{c}\text { BK Umbi } \\
(\mathrm{kg} / \tan )\end{array}$} & \multicolumn{2}{|c|}{$\begin{array}{c}\text { BK } \\
\text { Brangkas } \\
\text { an } \\
(\mathrm{kg} / \mathrm{tan})\end{array}$} & \multicolumn{2}{|c|}{$\begin{array}{c}\text { BK } \\
\text { Biomass } \\
(\mathrm{kg} / \mathrm{tan})\end{array}$} & \multicolumn{2}{|l|}{ IP $(\%)$} & \multicolumn{2}{|c|}{$\begin{array}{c}\text { Estimasi } \\
\text { hasil umbi } \\
\text { (t/ha) }\end{array}$} & \multicolumn{2}{|c|}{$\begin{array}{c}\text { Estimasi } \\
\text { Hasil } \\
\text { Brangkasa } \\
\mathrm{n}(\mathrm{t} / \mathrm{ha})\end{array}$} \\
\hline & & & * & 0.00 & & 0.002 & & 1252.5 & * & & $*$ & & * \\
\hline Rep & 2 & 0.0058 & $*$ & 55 & * & 2 & ns & 6 & $*$ & 94.85 & $*$ & 337.80 & $*$ \\
\hline Kultivar & 1 & & $*$ & 0.00 & $*$ & 0.005 & $*$ & & $*$ & & $*$ & & $*$ \\
\hline (main plot) & 2 & 0.0052 & $*$ & 43 & $*$ & 2 & $*$ & 946.57 & $*$ & 89.76 & $*$ & 239.35 & $*$ \\
\hline & 2 & & & 0.00 & & 0.001 & & & & & & & \\
\hline Error (a) & 4 & 0.0008 & & 13 & & 0 & & 202.79 & & 10.15 & & 50.77 & \\
\hline & & & $*$ & 0.00 & & 0.008 & $*$ & & & & $*$ & & $\mathrm{n}$ \\
\hline Biochar & 1 & 0.0075 & $*$ & 01 & $\mathrm{~ns}$ & 9 & * & 189.18 & $*$ & 128.32 & $*$ & 16.49 & s \\
\hline Kultivar x & 1 & & & 0.00 & & 0.000 & & & $\mathrm{n}$ & & & & $\mathrm{n}$ \\
\hline Biochar & 2 & 0.0003 & ns & 01 & $\mathrm{~ns}$ & 5 & ns & 22.03 & $\mathrm{~s}$ & 7.05 & ns & 7.01 & s \\
\hline & 2 & & & 0.00 & & 0.000 & & & & & & & \\
\hline Error (b) & 6 & 0.0004 & & 02 & & 7 & & 29.12 & & 8.39 & & 10.72 & \\
\hline
\end{tabular}

\section{Sebaran CH Bulanan Tahun 2017}

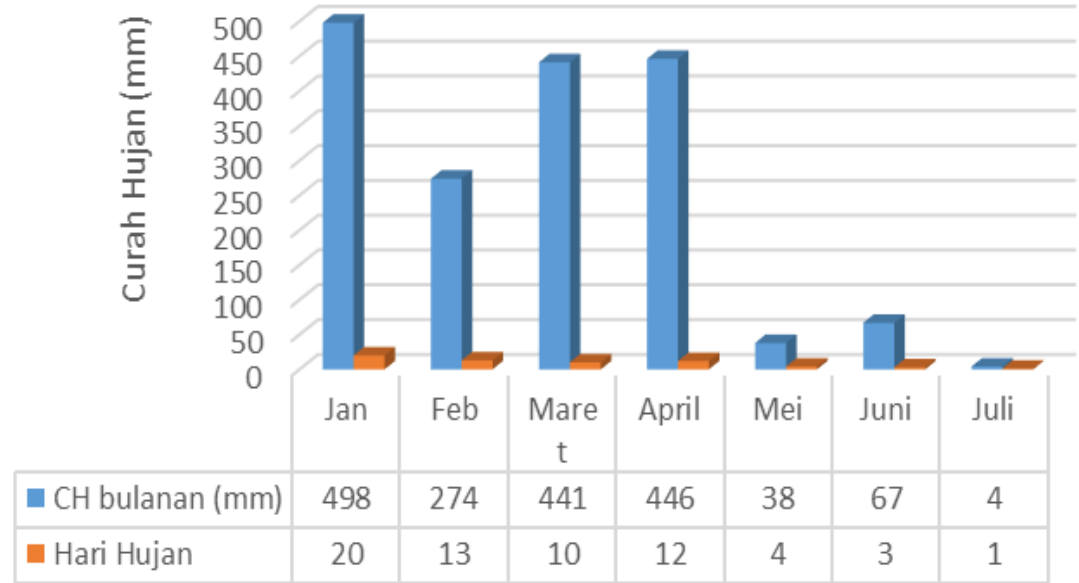

Gambar 1. Sebaran Curah Hujan dan hari Hujan selama penelitian berlangsung

Kondisi lahan tempat penelitian dilakukan memberikan gambaran adanya beberapa faktor pembatas, yakni $\mathrm{pH}$ tanah termasuk masam, C-organik dan $\mathrm{N}$-total maupun P-tersedia pada kondisi sangat rendah (Tabel 1). Di samping kondisi lahan, juga disajikan data sebaran Curah Hujan (CH) dan Hari Hujan (HH) selama pelaksanaan penelitian berlangsung, yakni pada bulan Maret sampai dengan Juli 2017 (Gambar 1). $\mathrm{CH}$ masih relatif tinggi pada awal pelaksanaan penelitian, ini cukup menguntungkan bagi tanaman yang ditanam dan menjelang panen $\mathrm{CH}$ sudah sangat rendah.

Indeks Panen (IP) dari semua kultivar yang dievaluasi menunjukkan ada perubahan ke arah positif atau meningkat ketika tanaman diberi biochar, tanpa perlakuan biochar IP kultivar ubijalar berkisar antara 41.63 - $77.76 \%$ dan meningkat menjadi $43.85-81.01 \%$ (Tabel 
5), kecuali kultivar Beta 1 yang IP-nya menurun akibat pemberian biochar.

\section{PEMBAHASAN}

Ubi jalar mudah diproduksi pada berbagai lahan dengan produktivitas antara 20-40 t/ha umbi segar (Zuraida dan Supriati, 2001), namun kenyataannya produktivitas di tingkat petani masih rendah, hanya mencapai 10 t/ha (Balitkabi, 2010). Demikian pula hasil penelitian ini menunjukkan belum tercapainya potensi hasil kultivar-kultivar ubijalar yang dievaluasi. Hasil ubijalar pada penelitian ini tercapai pada kisaran $8-21$ t/ha (Tabel 5). Pemberian biochar jengkok tembakau dengan dosis 5 t/ha mampu meningkatkan hasil umbi berkisar antara $8-45 \%$ dari hasil tersebut. Belum tercapainya hasil umbi disebabkan karena pada penelitian ini tanaman dipanen pada umur 3.5 bulan, seharusnya umur panen yang normal di daerah penelitian minimal 4 bulan setelah tanam. Di samping itu diduga ada faktor lain yang menjadi pembatas pertumbuhan dan hasil ubijalar tersebut, yakni kondisi kesuburan tanah dimana lokasi penelitian dilakukan. Beberapa faktor pembatas pertumbuhan tanaman seperti terlihat dari hasil analisis tanah (Tabel 1), yakni $\mathrm{pH}$ yang rendah (masam), kadar C-organik, $\mathrm{N}$ total dan P-tersedia yang sangat rendah. Disamping itu kemungkinan juga disebabkan terjadinya ketidak-seimbangan unsur hara yang ada, yaitu $\mathrm{K}, \mathrm{Na}$ dan $\mathrm{Mg}$ yang tinggi, Ca sedang.

Tanaman ubijalar mengambil unsur hara dalam tanah dalam jumlah yang relatif besar, menurut Zhang et al. (2017) dari hasil 19 kali percobaan diketahui bahwa untuk setiap ton hasil panen ubijalar diperlukan jumlah hara $\mathrm{N}, \mathrm{P}_{2} \mathrm{O}_{5}$ dan $\mathrm{K}_{2} \mathrm{O}$ masing-masing berkisar antara $2.30-7.58$ $\mathrm{kg} \mathrm{N}, 0.47-2.64 \mathrm{~kg} \mathrm{P}_{2} \mathrm{O}_{5}$ dan $1.59-11.47$ $\mathrm{kg} \mathrm{K}_{2} \mathrm{O}$. Apabila diasumsikan dapat dihasilkan $20 \mathrm{t}$ ubijalar/ha, maka ketiga unsur hara tersebut harus tersedia sebanyak masing-masing sebesar $4.6-151 \mathrm{~kg} \mathrm{~N}, 9.4$ - $52.00 \mathrm{~kg} \mathrm{P}_{2} \mathrm{O}_{5}$ dan $31.8-229.40 \mathrm{~kg} \mathrm{~K}_{2} \mathrm{O}$ per ha. Unsur hara yang tersedia berasal dari pupuk maupun yang terkandung di dalam tanah. Pupuk yang diberikan pada percobaan ini adalah PONSKA (15 15 15) sebanyak $400 \mathrm{~kg} / \mathrm{ha}$, dapat menyediakan sebanyak $60 \mathrm{~kg} \mathrm{~N}, 60 \mathrm{~kg} \mathrm{P}_{2} \mathrm{O}_{5}$ dan $60 \mathrm{~kg}$ $\mathrm{K}_{2} \mathrm{O}$. Dengan demikian dari pupuk yang diberikan, jumlah unsur hara yang kurang mencukupi adalah $\mathrm{N}$ dan $\mathrm{K}_{2} \mathrm{O}$, namun karena kadar $\mathrm{K}$ di dalam tanah tempat percobaan mengandung jumlah yang tinggi, kemungkinan unsur $\mathrm{K}$ tidak menjadi faktor pembatas. Yang menjadi faktor pembatas pada lokasi percobaan tersebut adalah unsur $\mathrm{N}$ bagi tanaman, karena kadar $\mathrm{N}$-total tanahnya sangat rendah. Asumsi kemungkinan kecukupan unsur hara tersebut belum memperhitungkan adanya faktor-faktor yang bisa menyebabkan tidak tersedianya hara disebabkan oleh pengaruh $\mathrm{pH}$ tanah dan jerapan unsur $\mathrm{P}$ oleh $\mathrm{Ca}$ atau $\mathrm{Mg}$ atau kompleks Al-Fe di dalam tanahtanah masam ataupun adanya sifat antagonisme antar unsur.

Penambahan biochar sebanyak 5 t/ha berpengaruh positif tehadap bobot umbi/hasil umbi segar, BK umbi, BK biomass, dan IP (Tabel 6 dan 7). Biochar biasanya sarat dengan kandungan amonium, nitrat, dan fosfat, sehingga bisa menjadi pupuk slow release untuk meningkatkan kesuburan tanah (Ding et al., 2016). Kadar $\mathrm{N}$ pada biochar jengkok tembakau sebesar $1.45 \%$ (data lengkap tidak disajikan), maka pemberian $5 \mathrm{t} / \mathrm{ha}$ dapat menyediakan $73 \mathrm{~kg}$ $\mathrm{N}$ bagi tanah dan tanaman. Namun pemberian biochar 5 t/ha dan pupuk PONSKA (15 15 15) dengan dosis 400 $\mathrm{kg} / \mathrm{ha}$ masih memberikan nilai keseimbangan hara $\mathrm{N}$ yang negatif terhadap kebutuhan $\mathrm{N}$ untuk ubijalar, karena apabila diasumsikan untuk menghasilkan 20 ton ubijalar diperlukan ketersediaan $\mathrm{N}$ sebesar $4.6-151 \mathrm{~kg} \mathrm{~N} / \mathrm{ha}$. N-tersedia dari pupuk dan biochar hanya sebanyak $133 \mathrm{~kg} \mathrm{~N}(=60$ $\mathrm{kg} \mathrm{N}+73 \mathrm{~kg} \mathrm{~N}$ ). Ketersediaan $\mathrm{N}$ dalam penelitian ini masih tetap menjadi faktor pembatas bagi pertumbuhan dan hasil ubijalar, sehingga hasil ubijalar segar yang dapat dicapai hanya berkisar antara 10.55 - 
22.70 t/ha (Tabel 5), meskipun pemberian biochar mampu meningkatkan hasil umbi berkisar antara $8-45 \%$ dari hasil tanpa penambahan biochar, kecuali untuk kultivar yang memberi respon negatif terhadap pemberian biochar jengkok tembakau (Beta 1 dan Boko).

Budiaya pertanian secara jangka panjang dapat menyebabkan degradasi, mengasamkan tanah, penurunan bahan organik tanah, dan erosi tanah yang parah. Sitorus et al. (2011) menyebutkan bahwa tanah-tanah dengan tekstur fraksi debunya pada kisaran $20-40 \%$ dan ketersediaan $\mathrm{P}$ yang sangat rendah, termasuk pada kondisi tanah yang telah terdegradasi sedang. Lahan di lokasi percobaan mempunyai fraksi debu sebesar 35\%, C-organik, N-total dan P-tersedia sangat rendah (Tabel 1), dan lahan tersebut telah digunakan untuk budidaya tanaman secara intensif, sehingga tingkat degradasi lahannya sudah berada pada katagori yang sedang - berat. Menurut Ding et al. (2016), penurunan bahan organik tanah mengakibatkan penurunan stabilitas agregat tanah, sehingga dengan kadar bahan organik yang sangat rendah tanah menjadi sangat rawan terhadap erosi. Oleh karena itu, sangat penting untuk memperbaiki tanah degradasi dengan metode sederhana dan berkelanjutan, yakni dengan pemberian bahan pembenah tanah yang berupa biochar. Biochar jengkok tembakau memberi pengaruh positif terhadap hasil umbi segar kultivar-kultivar ubijalar.

\section{KESIMPULAN}

(1) Kultivar-kultivar ubijalar memberikan respon yang sangat nyata terhadap pemberian biochar jengkok tembakau sebesar $5 \mathrm{t} / \mathrm{ha}$, terutama pada bobot umbi, bobot kering umbi, bobot kering biomass, IP dan estimasi hasil umbi segar per hektar.

(2) Potensi hasil umbi dan brangkasan segar masih belum tercapai, hanya berkisar antara $8-23 \mathrm{t}$ umbi dan $5-24$ t brangkasan pada umur panen 3.5 bulan setelah tanam.

(3) Ketidak-tercapaian hasil umbi dan brangkasan diakibatkan oleh adanya beberapa faktor pembatas C-organik, N-total dan P-tersedia yang sangat rendah.

(4) Peningkatan hasil umbi ubijalar sebagai respon pemberian biochar jengkok tembakau bisa mencapai $8-45 \%$ dibandingkan tanpa pemberian biochar.

\section{UCAPAN TERIMA KASIH}

Ucapan terima kasih disampaikan kepada DRPM-Kemenristek Dikti yang telah mendanai Hibah PUPT Tahun 2017. Hal serupa disampaikan kepada Balitkabi yang menyediakan beberapa varietas ubijalar yang telah dilepas, FP-UB yang mengijinkan penulis melaksanakan penelitian dan menyimpan koleksi klonklon ubijalar hasil penelitian yang digunakan dalam penelitian ini. Ucapan terima kasih juga disampaikan kepada Stasiun Klimatologi Karangploso atas dukungan data $\mathrm{CH}$ dan $\mathrm{HH}$ yang telah diberikan.

\section{DAFTAR PUSTAKA}

Balitkabi. 2010. Teknologi Produksi Ubijalar. Balitkabi. litbang. pertanian.go.id (diakses tanggal 10 September 2017).

Ding Y, Liu Y, Liu S, Li Z, Tan X, Huang X, Zeng G, Zhou L, Zheng B. 2016. Biochar to improve soil fertility. A Review. Agronomy for sustainable development. 36(2), pp.36.

Kozai T, Kubota C, Kitaya Y. 1996. Sweetpotato technology for solving the global issues on food, energy, natural resources and environment in the 21st century. (Japanese text.) Environ. Control in Biol. 34:105114.

Motsa NM, Modi AT, Mabhaudhi T. 2015. Sweet potato response to low-input 
agriculture and varying environments of KwaZulu-Natal, South Africa: implications for food security strategies. Acta Agriculturae Scandinavica, Section B-Soil and Plant Science. 65(4): 329-340.

Saleh N, Hartojo K. 2003. Present status and future research in sweetpotato in Indonesia. In K.O. Fuglie (Ed.). Progress in Potato and Sweetpotato Research in Indonesia. CIP-ESEAP and IAARD. pp. 137-153.

Sheth SG. 2017. Effect of integrated nutrient management on growth, yield and quality of sweet potato [Ipomoea batatas Lam]. IJCS. 5(4): 346-349.

Sitorus SR, Susanto B, Haridjaja O. 2011. Kriteria dan klasifikasi tingkat degradasi lahan di lahan kering (Studi kasus: Lahan kering di Kabupaten Bogor).

Talkah, A. 2010. Prospek Limbah Jengkok Tembakau Industri Rokok Sebagai
Pupuk Organik Dengan Baku Mutu Nasional (Menuju Pertanian Organik Ramah Lingkungan). Uniska Press Kediri Jl. Sersan Suharmadji 38 Kediri.

Zhang YC, Wang JD, Shi YX, Ma DF. 2017. Nutrient Management for high efficiency sweet potato production. Phytonutritional Improvement of Crops, 471-497.

Ziska LH, Runion GB, Tomecek M, Prior SA, Torbet HA, Sicher R. 2009. An evaluation of cassava, sweet potato and field corn as potential carbohydrate sources for bioethanol production in Alabama and Maryland. Biomass and Bioenergy. 33(11): 1503-1508.

Zuraida, Supriati NY. 2001. Usahatani ubi jalar sebagai bahan pangan alternatif dan diversifikasi sumber karbohidrat. Buletin agrobio.4(1): 13-23. 